\title{
Cuatro calas en la novela española actual: Esther García llovet, Mario Cuenca Sandoval, Andrés Neuman y Aroa Moreno Durán
}

\author{
FERNANDO VALLS \\ Universidad Autónoma de Barcelona
}

\section{RESUMEN:}

La novela española actual, la que ha surgido en el siglo XXI, está dando frutos muy diversos en sus distintos registros estéticos, lingüísticos y temáti$\cos$. Buena prueba de ello son las cuatro narraciones de las que aquí nos ocupamos. La aceleración de la historia actual, junto con los conflictos relativos a la vida cotidiana proporcionan al narrador de nuestros días materia más que suficiente para que, a través de la ficción, podamos comprender algo mejor nuestro mundo, ya se trate del presente, ya del pasado que sigue condicionándonos.

\section{PALABRAS CLAVE:}

Narración, novela, novela corta, española, actual.

\begin{abstract}
:
The current Spanish novel, which has emerged in the 21 st century, is bearing very different fruits in its different aesthetic, linguistic and thematic registers. Good proof of this are the four narrations that we are dealing with here. The acceleration of current history, together with the conflicts related to everyday life, provide the narrator with more than enough material so that, through fiction, we can understand our world better, whether it is the present, past that continues conditioning us.
\end{abstract}

\section{KEYWORDS:}

Narration, novel, short novel, Spanish, current..

Voy a ocuparme de tres novelas y de una novela corta recientes, de otros tantos autores. Dos de ellas han obtenido premios prestigiosos, o al menos de aquellos que no suelen contribuir a la confusión: el Ciudad de Barcelona, la novela de Cuenca Sandoval, y el Ojo Crítico, la de Moreno Durán. Pero quizá lo más interesante sea que responden a inquietudes y estéticas distintas, abordando temas y mundos diferentes. Neuman es un autor hispanoargentino, diría que ya consagrado, pues tiene en su haber una excelente novela, con la que obtuvo el Premio de la Crítica, El viajero del siglo (2009). Además de la novela, ha cultivado también la poesía, el cuento, el microrrelato, el aforismo y el ensayo. Cuenca Sandoval, con su última obra, me 
parece que ha dado un importante paso adelante, ya lejos de las gracietas y de las huecas pretensiones de los llamados nocilleros. García Llovet es una escritora singular, que transita por caminos diferentes, aunque me parezca que sus mejores obras estén todavía por llegar. Y Moreno Durán, tras cultivar la poesía, ha logrado llamar la atención e interesar a los lectores y a los críticos con su primera novela. Los sucesos de Sánchez, la primera narración de la que voy a ocuparme, transcurren en Madrid, aunque se centre en unos lugares de la ciudad en los que apenas se había ocupado la ficción. Los de la segunda, El don de la fiebre, ocurren en Francia y Alemania. La tercera, Fractura, en varias ciudades de Japón, en París, Nueva York, Buenos Aires y Madrid. Y la última, La hija del comunista, en las dos Alemanias separadas por el muro, pero sobre todo en Berlín. Por tanto, sin que falten las historias locales, predominan las globales. Mi intención, pues, al elegirlas ha sido que los lectores puedan hacerse una idea de lo que escriben los nuevos narradores, aquellos que iniciaron su trayectoria literaria en el siglo XXI, y ese objetivo quizá pueda alcanzarse leyendo estas historias acaso representativas del conjunto, aunque otras distintas pudieran serlo igualmente. Lo indudable es que estas narraciones no forman parte de los habituales aspavientos que ha traído consigo la denominada posmodernidad tardía. Y, por último, el azar, y los buenos oficios de sus editores, ha hecho que aparecieran en editoriales significativas: Anagrama, Seix Barral, Alfaguara y Caballo de Troya. Esta última, una etiqueta modesta pero amparada por un gran grupo, Penguin Random House, se ha convertido en la plataforma de lanzamiento de numerosos escritores jóvenes, españoles e hispanoamericanos, que han iniciado aquí una trayectoria que se augura brillante, como ha ocurrido en los casos de Marta Sanz, Lina Meruane, Elvira Navarro, Cristina Morales, Julián Rodríguez, Mercedes Cebrián, Damián Tabarovsky, Raúl Quinto y Gabriela Ybarra, por solo citar a aquellos que me han interesado más.

Sánchez (Anagrama, Barcelona, 2018), de Esther García Llovet (Málaga, 1963) es una novela corta compuesta por trece capítulos sin numerar cuya acción se desarrolla a lo largo de la peculiar noche de agosto que es la de San Lorenzo, mientras la narradora va contando las horas en que transcurre la acción hasta llegar a las siete de la mañana, cuando se celebrará una carrera de galgos que se supone que debe favorecer los intereses de los protagonistas. Así, por ejemplo, el tercer y el quinto capítulo empiezan anunciando la hora en que se desarrollan los acontecimientos: las tres y cuarto de la madrugada, en el primer caso, y las cinco de la mañana en el otro. En ellos se nos cuenta cómo un par de jóvenes, Nikki y Daniel Sánchez, que habían formado pareja y vivido juntos, recorren Madrid para finiquitar un negocio. Pero antes van en busca de Bertrán, luego de un galgo perdido y finalmente de la italiana Taziana Filardi, a la que pretenden vendérselo por ocho mil euros, una vez que han 
Cuatro calas en la novela española actual:...

conseguido recuperar ese galgo de carreras que lleva el estrambótico nombre de Cromwell, negocio que los sacaría de las penurias que arrastran.

Contado así, parece poca cosa, y nos lleva a pensar que resulta difícil armar una novela, incluso una novela corta, con menos mimbres, y sin embargo dan suficiente juego, pues se trata de acompañar a los personajes a lo largo de un recorrido por un Madrid poco frecuentado en la narrativa, alumbrado en esta ocasión por la pirotecnia habitual de la noche de San Lorenzo, con sus estrellas fugaces. Podría decirse, por tanto, que la sobriedad de la historia que se cuenta, y la del espacio físico en que transcurre la acción, contrasta con el despliegue de astros que recorren el firmamento. Además, los protagonistas, en su vagar nocturno a través de las timbas, los bares regentados por chinos, un bingo, los alrededores de las estación de Chamartín, el intercambiador de la plaza de Castilla y Mercamadrid, se dedican a robar cobre y nos enseñan el manido truco del cubilete o los frascos de asteroides con los que pretenden comerciar.

La novela está contada en primera persona por Nikki, aunque las conversaciones que mantenga con Sánchez, a veces parco en sus réplicas, ocupen una parte importante del relato. A ese respecto, la narradora confiesa: «Yo era muy buena dando palique, lo sigo siendo. En realidad hablo mucho porque cuando hablo no pienso y entonces ya no puedo parar de hablar» (pág. 85). A los frecuentes diálogos habría que sumarles las rememoraciones del pasado, que se refieren sobre todo a cómo se conocieron y a qué relaciones mantuvieron en el pasado los tres principales protagonistas: Nikki, Sánchez y Bertrán. Ella, cuya existencia se desarrolla en los márgenes, adopta el lenguaje más adecuado para mostrarnos el mundo y las gentes entre las que se desenvuelve ( sin saltarse casi ninguno de los lugares comunes a la moda del día, o trastocando alguna frase hecha: el con quién nos las vamos a ver se convierte en con quién nos las vamos a medir), dada su condición de trapicheadora marginal, aunque paliando los excesos, para no caer en el costumbrismo linguístico, lo que hubiera asfixiado la narración. Sin embargo, no faltan las frases sentenciosas, con su peculiar ingenio; una especie de filosofía de la supervivencia que aboga por el desprecio del mundo $^{1}$; e incluso un diálogo sobre la metáfora que parece sacado de Beckett (pág.

\footnotetext{
${ }^{1}$ Cito algunas de ellas: Oigo arder hasta el filamento de las bombillas (pág. 11); El hombre guapo no se pierde por la calle (pág. 25); Sonaba el chirrido del pequeño resorte que pone en marcha el mecanismo de la noche (pág. 28); Nunca subestimes la soberbia del panoli español (pág. 29); En una barba de dos días puede encenderse una cerilla, duros pelos rojos y amarillos donde empezar una revolución (pág. 29); Con el tiempo me ocurre siempre como con el dinero, cuando me pongo a perderlo, lo pierdo todo (pág. 32); Pastillas, pastis, pirulas. Esta es la materia de la que están hechas las civilizaciones (pág. 39); El gran espectáculo de Mercamadrid, ese botín producto del saqueo diario del arca de Noé (pág. 51); Era un peruano de pelo duro y dientes tan blancos que parecía que llevara el cuarto de baño metido en la boca (pág. 61); Yo al Papa le mangaría muchas cosas, condelabros,
} 
57). Los espacios por los que deambulan son abiertos cuando remiten a la ciudad, a los parques, pero cerrados en el caso del coche que los lleva de acá para allá.

Nikki, desde su subjetividad, describe a Sánchez y Bertrán como raros y guapos. En la rareza de uno y en los superpoderes o dones del otro, se insiste en diversas ocasiones. Al primero, lo tacha la narradora de guapo tímido y melancólico que, en un momento dado, se define como gafe, invisible y un fantasma, afirmando que esos son precisamente sus atributos. En cambio, apenas se describen las relaciones sexuales, ni amorosas; solo unos peculiares vínculos de amistad, aunque sería mejor decir de complicidad, o como Nikki puntualiza ante Sánchez: "Yo no tengo amigos, tengo colegas» (pág. 113), que se generan entre seres que viven al margen de la sociedad burguesa. Aun cuando ellos tres proceden de clases sociales distintas: Bertrán forma parte de una familia bien, aunque extravagante, «un pijo raro pero de los listos» (pág. 98). Mientras que Nikki comenta que era filóloga, pero «la filología no tiene que ver con nada», y remata la sentencia: «Yo antes era filóloga, sí, iba a ver pelis iraníes, dejaba propina, adelantaba por la izquierda. Hay que ver qué rápido acaba la ruina con la verdad» (pág. 101). El caso es que no escasean los personajes extrambóticos, como son las gemelas Tilda y la otra; Roque, el peruano; o Mardones y sus retiros espirituales.

La dejadez y el escepticismo lo preside todo durante unas horas que la narradora -cuando nos acercamos al desenlace- califica de «noche de mierda» (pág. 125). Sea como fuere, el caso es que solo se mueven para sacar dinero, para sobrevivir. Pero ¿por qué se llama la novela Sánchez y no Nikki o Bertrán? Pues porque todo gira en torno a él, a los comentarios que le dedica la narradora y a las conversaciones que mantiene con ella. Incluso aparece una curiosa alusión a su apellido: «No sé por qué. Su nombre de pronto me sonaba a canción del verano, de verano de los setenta con mucha espuma de color, una canción de Peret» (pág. 116). Quizás el cuarto protagonista sea el galgo perdido y hallado, que sale en la foto de la cubierta, donde parece que sobrevuela la ciudad. No quisiera acabar este breve comentario sin llamar la atención sobre el comienzo del capítulo 5 en el que, por medio de la reiteración de una palabra, se multiplica la presencia en Madrid de los chinos, pues en ocho líneas se alude a ellos en quince ocasiones (pág. 44); o sobre la alusión a la performance de Marina Abramovic, aunque no se la cite, a la que asiste Bertrán (pág. 118).

mapas de América, mármoles de Raffaella Carrara, aunque igual me bastaba con esos Manolos color púrpura que tiene, tan chulos, tan suaves, un par al día que debe estrenar, no vaya a salirle cayo de pisar el mundo (pág. 65); Hay que ver qué rápido pasa el tiempo cuando le debes dinero a alguien (pág. 76); Las rotondas, esas indecisiones tan españolas (pág. 91); y, por último, El pálido resplandor de la pantalla del móvil, esa luz que nos habla (pág. 102). 
Cuatro calas en la novela española actual:...

¿Consiguen vender el galgo, que tampoco sabemos si es un timo (en la novela, «un fake») y salir de la ruina? Son preguntas sin respuesta. En cualquier caso, la narración concluye no con un final sorpresivo, sino con unos golpes de efecto, pues al recorrido de la estrella fugaz, de este a oeste, se suman las palabras de la narradora: «esto ha sido magia violenta contra miedo melancólico». Y todo ello ocurre en la frase final de esta narración, para recordarnos «lo invisible y la verdadera naturaleza de las cosas» (págs. 129 y 130). En suma, si esto hubiera sido una reseña quizá la hubiera titulado «Raros y nocturnos en una noche madrileña de San Lorenzo».

Mario Cuenca Sandoval (Sabadell, 1975) es poeta y narrador, autor de novelas y cuentos. En esta nueva narración extensa, El don de la fiebre (Seix Barral, Barcelona, 2018), la cuarta suya, nos cuenta en 66 capítulos, divididos en 6 partes, algunos de los principales episodios de la vida de Olivier Messiaen (1908-1992), el fervor por la música de un autor de piezas que se consideran fundamentales para entender el siglo XX, tales como el Cuarteto para el fin del tiempo (1941), compuesta, según se describe, por ritmos irregulares, armonías modales y disonancias (pág. 159), y San Francisco de Asís (1983). Messiaen fue alumno de Paul Dukas y Marcel Dupré, y maestro, a su vez, de Pierre Boulez y de Stokhausen.

Los títulos de las distintas partes en que se divide la narración aparecen relacionados; no en vano, la segunda, cuarta y sexta se titulan, respectivamente: «El ensimismado», «El estigmatizado» $\mathrm{y}$ «El deslumbrado», en clara alusión al protagonista. Mientras que la primera, tercera y quinta partes remiten a conceptos (la luz, el oído, los ángeles, el tiempo y los colores) que, a lo largo de la novela, adquieren protagonismo: «La luz en el oído», «El ángel del fin del tiempo» y «El color del tiempo», se titulan. A Messiaen le tocó vivir «un tiempo sin tiempo que era preciso moldear con la música» (pág. 103). A todos estos paratextos, habría que añadir la cita inicial, de Juan Ramón Jiménez, muy significativa: «¿Por qué comemos y bebemos otra cosa que luz o fuego?», con la que podría estar aludiendo a las inquietudes espirituales de todo creador.

Por muchas razones, Messiaen puede considerarse un músico atípico, pues a su condición de católico, debe añadirse su creencia en la sinestesia (presente en los títulos de las partes impares de la novela; en su caso, en la vinculación de la música con los colores) y su fascinación por la naturaleza, por la ornitología, de ahí el protagonismo que adquiere en sus obras el canto de los pájaros, del mirlo... Fue compositor e intérprete de la Vanguardia y, durante gran parte de su vida, organista en la iglesia de la Santísima Trinidad, de Montmartre. Participó en la Segunda Guerra Mundial, y fue internado a lo largo de siete meses de 1941 en el campo de prisioneros Stalag VIII-A, en Görlitz, Silesia, cerca de la frontera con Polonia, donde, por cierto, también estuvo el fotógrafo Cartier-Bresson. A todo ello habría que añadir, por último, 
la grave enfermedad mental de su primera esposa, a quien solía llamar «Mi», la violinista y compositora Claire Delbos, de quien pronto se alejó, también de su hijo Pascal, pues representaban para él la vida doméstica. Pero si en este relato la historia actúa siempre como fondo que condiciona la vida de las personas, es la creación artística su motor principal.

El lector más inquieto se preguntará si se trata de una novela o de una biografía novelada. El autor, en un «Post scriptum», la define como «una reconstrucción literaria de la peripecia vital de Olivier Messiaen» (pág. 329), por tanto, sería una novela. Yo la he leído como tal, pues no se propone narrar una vida completa, sino solo algunos retazos que nos muestren quién fue Messiaen, la persona y el músico, en la que el autor maneja con rigor los datos históricos, pero parte-como ocurre con la ficción- de donde se detiene la Historia, valiéndose de los mecanismos habituales de la ficción, de sus voces narrativas, estructura y retórica, para contar los avatares de una época y de la vida de un artista comprometido con su arte, la interpretación y la composición. Si, al fin y a la postre, Messiaen consigue salvarse, sobrevivir, quizá sea debido a su ensimismamiento y a su vocación, amparado además por la fe y su arte.

Pero vayamos a alguno de los títulos. El de la novela se refiere al estado creativo, entre la visión, el ensueño y la alucinación (págs. 76, 123, 125, 248 y 326). Y en una de sus obras mayores, con el fin del tiempo apela a la eternidad, al fin de la Historia, pues cuando llegue el Reino, y no poseemos más reino que el interior, nos aclara, el tiempo dejará de existir -como anuncia el ángel-desapareciendo por tanto la guerra y el dolor (págs. 118, 134, 150 y 162). Por el contrario, para los nazis, con ellos empezaba un tiempo nиevo. En definitiva, según Messiaen, la música debería escapar de la tiranía del tiempo, como escapa el alma de la tiranía de la carne... (pág. 134), pero además, a través de su mediación, propone, alcanzaremos la verdadera luz y el amor terrenal se convertirá en amor puro (págs. 145, 149 y 162). Todas ellas son metáforas que pueden iluminar tanto los trágicos avatares del último siglo como los misterios de la creación, junto con los claroscuros en que se desenvolvió la existencia de este músico y que el autor no evita referir.

La Naturaleza y la Historia desempeñan también un papel importante, pues la belleza natural es una especie de atajo para alcanzar la belleza eterna (pág. 290). Así, los dos momentos clave de la novela quizá sean el concierto en el campo de prisioneros y las reflexiones finales sobre la enfermedad y la muerte del protagonista. Pues lo que, en suma, se nos cuenta es que «la creación artística (...) es una travesía solitaria y exige del creador una existencia vuelta hacia sí. Desentendida de los otros, desentendida de lo común...» (págs. 138 y 139). De todo ello se desprende que la música 
Cuatro calas en la novela española actual:...

nos humaniza, nos eleva y puede hacernos mejores, más libres y, por consiguiente, más felices.

En Fractura (Alfaguara, Madrid, 2018), de Andrés Neuman (Buenos Aires, 1977), se cuenta la historia de un hombre, el japonés Yoshie Watanabe, y de las cuatro mujeres, Violet, Lorrie, Mariela y Carmen, con quienes mantiene a lo largo del tiempo relaciones sentimentales en las distintas ciudades en las que coinciden sus vidas. Se trata de un emigrante temprano, «un alma en tránsito», tal y como lo ha definido el autor, que trabaja a sueldo de una multinacional de la electrónica, recorriendo el mundo con su colección de banjos (págs. 24, 68, 208, 411, 432 y 440). Así, vive en el París de la postguerra y la Nouvelle Vague con Violet; entabla su primera relación -digamos- formal con Lorrie, una judía que trabaja como periodista cultural en el Nueva York que sufre la resaca de Vietnam y del Watergate; se instala en Buenos Aires cuando está a punto de estallar la guerra de las Malvinas, en 1982, relacionándose con Mariela; y comparte un amor otoñal en la España que acababa de incorporarse a la Unión Europea, en el Madrid que apenas surge de la Transición, con Carmen. Y en ese afán de ir de acá para allá, sin descanso, el narrador externo iguala su destino al de Chéjov (pág. 263). De modo que a partir de todos estos mimbres diversos va haciéndose una identidad múltiple, influido por las mujeres con las que compartió su vida.

Watanabe vivió la exploxión atómica de Hiroshima (1945), en la que perecieron sus allegados más cercanos, y se libró de milagro de la de Nagasaki. Pero ahora, en el presente narrativo, comprende que no le queda más remedio que enfrentarse al desastre nuclear de Fukushima (2011), ocurrido veinticinco años después del de Chernóbil, como si de un nuevo aviso se tratara ${ }^{2}$. Yoshie es un hibakusha, un superviviente de las bombas atómicas. El caso es que la novela nos alienta a reflexionar sobre las consecuencias de estas tragedias, sobre la historia de un país que tropieza de nuevo en la misma piedra, a cuestionar el papel que ha desempeñado la energía en el desarrollo de la sociedad y el escaso cuidado que se le ha prestado al medio ambiente. Es, sin duda, un grave problema que afecta a todo el orbe, que Neuman presenta como un mundo interconectado. Por tanto, nos concierne también a nosotros, pues no en vano la central de Garoña (Burgos) es semejante a la de Fukushima. Antes de seguir, permítanme un breve paréntesis para recordar que existen varios relatos en la literatura española sobre los efectos de la bomba atómica. Se me ocurren ahora cinco ejemplos lejanos en el tiempo: Uranio 235, pieza de teatro de Alfonso Sastre, estrenada en 1946, y un microrrelato de este mismo autor al que luego me referiré; un poema de José Ángel Valente, «Hibakusha», incluido en Al dios del lugar (1989);

\footnotetext{
${ }^{2}$ El desastre nuclear de Chernóbil, ciudad situada entre las actuales Bielorrusia y Ucrania, ocurrió en 1986. Miles de personas tuvieron que ser evacuadas en un radio de 4.200 kilómetros.
} 
«Little Boy», cuento de Marina Perezagua recogido en su libro Leche (2013); y el reciente Un andar solitario (Seix Barral, Barcelona, 2018), de Antonio Muñoz Molina, en mi opinión más un diario que una novela, donde se alude a Fukushima (págs. 337 y 338). Fractura, ambiciosa narración que trata sobre la memoria, el olvido, los traumas y la culpa, se compone de once capítulos y una «Nota del autor» final en la que despliega sus fuentes, entre las cuales se cita al escritor y director de cine Ryu Murakami y a los escritores Kenzaburo Oé y Cynthia Ozick. A ellos podrían añadirse otros nombres que se han ocupado de esos mismos temas, además de las consideraciones que aparecen en la novela (págs. 312 y 313).

De los once capítulos, cinco reproducen en su título el mismo esquema: el nombre de un personaje y un atributo que metaforiza lo que va a contarse. Entre ellos, en concreto, los cuatro primeros capítulos están narrados en primera persona por las mujeres que formaron pareja con Watanabe, quienes nos proporcionan sus recuerdos e impresiones sobre la relación que mantuvieron. Mientras que en el título restante aparece el periodista argentino Pinedo. Los demás capítulos, todos los impares y el último de los pares, el 1, 3, 5, 7, 10 y 11, los conduce un narrador externo en tercera persona. Esta perspectiva múltiple hace el relato más sugerente, plural y complejo. Si nos fijamos, además, en el conjunto de los títulos, tres de ellos forman parte de un mismo campo semántico que resulta definitorio: fractura, cicatrices y contracturas.

Según ha confesado Neuman, su interés por Japón viene de lejos, pero el acicate principal y el punto de partida para escribir esta novela fue el tsunami que asoló la costa de Japón el 11 de marzo del 2011, poniendo en grave peligro la central nuclear de Fukushima. A ello debe sumarse otra historia real, la de Tsutomu Yamaguchi, que sobrevivió a los bombardeos de Hiroshima y Nagasaki, falleciendo a los 93 años, convirtiéndose así - podría decirse- en el hombre del que se olvidó la muerte... En cierta forma, le ocurrió lo mismo al protagonista, quien de no haber perdido un tren habría perecido en la explosión que asoló Nagasaki. En un microrrelato de Alfonso Sastre títulado «Nagasaki», incluido en un libro de 1964, el protagonista, Yanajido, también sufre la doble tragedia. Pero la pregunta clave que debemos formularnos, regresando al hilo principal de la argumentación, es por qué algunos países, como Japón, sustentaron su desarrollo precisamente en aquello que podría destruirlos.

El apellido del personaje proviene del poeta peruano José Watanabe (1945-2007), cuyos versos aparecen en una de las citas que encabeza la novela, que junto a las tres citas restantes - de autores muy distintos en sus orígenes, tradiciones y génerosanticipan en esencia algunas de las cuestiones principales que se plantea el autor. Se trata de un individuo que a lo largo de la narración utiliza cuatro lenguas distintas (japonés, francés, inglés y español), entre ellas dos variantes del castellano, el que 
se habla en Argentina y el de España, que son los que habitualmente suele manejar el autor y que podrían suponer otros tantos cambios de piel. Pero, además, en el fraseo de Violet y Lorrie, tanto en el léxico como en la sintaxis, aparecen galicismos y anglicismos para producir en el lector la ilusión de que sus voces están siendo traducidas al español. Así, uno de los logros más evidentes de la narración consiste en esa variedad de perspectivas y registros, sin olvidarnos del tono propio del narrador y, por tanto, en esas maneras diferentes de pensar, de encarar la realidad. A este propósito, las voces mas logradas quizá sean las de Violet y Mariela. Podrían sumarse a ello los diversos recursos -digamos- retóricos y lingüísticos que maneja o las reflexiones sobre el uso del lenguaje (págs. 27, 29, 39, 104, 106, 134, 156, 253, 254, 334 y $485 \ldots$..). Así, por ejemplo, los cambios de léxico, o la utilización de lo que en la novela se denomina un «lenguaje tóxico» (pág. 379).

Uno de los temas principales que se plantea es cómo el trauma padecido puede afectar a los supervivientes, y de qué manera logran seguir viviendo las víctimas: ¿con el silencio, o verbalizando la experiencia? La respuesta de Neuman es que si bien resulta imprescindible seguir adelante, no es menos necesario haber mirado hacia atrás con honestidad. Para ilustrarlo, se vale de la metáfora del kintsugi, un arte ancestral japonés que consiste en reparar un objeto roto realzando con hilos de oro las líneas por las que se quebró, un modo de dejar testimonio de su existencia, cuya representación simbólica aparece en la ilustración de la cubierta ${ }^{3}$. Pero si aplicamos la metáfora a las personas, a Watanabe en concreto, y a las cicatrices que ha ido acumulando durante su existencia, puede observarse la evolución que sufre el personaje a lo largo de la narración. Esta postura contrasta con la de Carmen, la pareja española de Yoshie, que prefiere mirar hacia el futuro, dejando de lado el pasado. Frente al cirujano de hierro que prescribió Joaquín Costa, para enmendar los males de la patria, por decirlo con Lucas Mallada, Carmen apuesta con ironía postmoderna por un osteópata («Moverle la estructura pero bien») o por «un poquito de hidroterapia, para que la cosa fluya») (pág. 443).

Se nos cuentan, además, siempre desde el punto de vista de las respectivas mujeres, cuatro historias de amor que suceden en momentos vitales diferentes, por lo que acabamos teniendo otras tantas versiones no solo de Watanabe, sino también un catálogo de las relaciones sentimentales que se corresponden con distintas edades de la vida, a las que podría sumarse aquella que se desprende de lo que relata el narrador y que cada lector acabará formándose. La crítica se ha planteado, con división de opiniones, el papel que desempeña en la narración el periodista argentino Jorge Pinedo, quien sufre su propia crisis, insatisfecho con su trabajo, pero empeñado en

\footnotetext{
${ }^{3}$ Sobre el reiterado interés por esta práctica, véase el reciente artículo del pintor Joan-Pere Viladecans, «El arte del kintsugi», Cultura/s. La Vanguardia, 12 de mayo del 2018, pág. 17.
} 
escribir una serie de artículos sobre los accidentes nucleares, para convertirse en un periodista de más fuste y acaso también en un autor de ficción. Se trata, por tanto, de una mirada profesional externa a los hechos, aunque se muestre obsesionado por el tema. Así, no solo intenta sonsacarle información sobre su trayectoria vital al protagonista, quien no le hace caso alguno, sino también a sus parejas, hasta el punto de coquetear con Mariela, amiga de su madre. Pero su papel adquiere más consistencia si entendemos que todas estas narraciones, a la manera cervantina, se contienen unas a otras. Así, la vida de Watanabe es narrada por cuatro mujeres; todo ello es, a su vez, contado por el periodista; y finalmente un narrador externo y omnisciente nos lo transmite.

El espacio, los países y ciudades, los caracteres de sus gentes y las identidades también adquieren en la novela un importante protagonismo, tanto por sí mismos como por las comparaciones que van estableciéndose entre unos lugares y otros, sobre la vida en las grandes ciudades en las que habita (compara Buenos Aires primero con Nueva York y luego con París y Madrid; Japón con España...), y sobre todo por el contraste final con el paisaje desolado de los alrededores de Fukushima, a la que va acercándose el ya maduro Watanabe. Así, empieza abandonando su país para estudiar una carrera, pero cuando muchos años después, ya jubilado, regresa definitivamente a Japón, se aisla en su piso, situado en un rascacielos de Tokio, casi ajeno al mundo que lo rodea, incómodo ante la conducta de los jóvenes y empeñado en ignorar las llamadas redes sociales. Pero su objetivo último estriba en encaminarse al epicentro del drama, a la zona donde ha resurgido el horror. Podría decirse, por tanto, que se trata de un viaje con tintes quijotescos que concluye con un descenso a los infiernos, en el que le resulta mucho más doloroso el regreso a su país que la huida. No en vano, el capítulo décimo se titula «Último círculo». En él, Watanabe va acercándose a la central, recorriendo un paisaje devastado, mientras intenta relacionarse con las escasas gentes que no han abandonado esos lugares, los ancianos y los niños a su cuidado. Al fin y a la postre, lo que se desprende de la existencia de Yoshie, un hombre cercado por las catástrofes nucleares, las del pasado y la del presente, y por las mujeres que han ido moldeándolo a lo largo del tiempo, es que para poder seguir adelante no tiene más remedio que mirar atrás, pero también debe intentar ser consciente de haber sido una víctima, de su condición de superviviente. En el desenlace, cuando se acerca a Fukushima, la narración tiende a la abstracción lírica, a la constatación de las meras sensaciones, como ocurre también en el arranque, sobre todo en el excelente párrafo final de la página 18.

Toda la novela, una pura tragicomedia, se resuelve en un juego de compensaciones, tanto en los contrapuntos de las voces como en los caracteres de los personajes, en los diversos tonos y registros que adopta, entre lo sarcástico, lo transcendente y un 
cierto humor irónico. Ante un despliegue tan apabullante de intenciones y medios, lo más probable sería salir trasquilado, aunque el mero empeño ya hubiera sido digno de alabanza, en un momento en el que la novela española se muestra a menudo tan contentadiza. No ha sido así, puesto que Neuman no solo sale airoso sino que también ha logrado escribir otra gran narración, raspando en calidad y alcance a su extraordinaria El viajero del siglo. Creo que, entre los escritores de su edad, muy pocos han alcanzado semejante nivel de excelencia.

Por último, La hija del comunista (Caballo de Troya, Madrid, 2017) es la primera novela de Aroa Moreno Durán (Madrid, 1981), que ya tenía en su haber dos libros de poemas que siento no conocer: Veinte años sin lápices nuevos (2009) y Jet lag (2016). Con ella ha obtenido el Premio Ojo Crítico a la mejor novela del 20174. Está formada por un breve inicio en el que habla un narrador omnisciente, y cuatro partes tituladas («El este», «La tierra de nadie», «El otro lado» $\mathrm{y}$ «Vaterland [la tierra de mi padre]»), de muy diferentes dimensiones, pues se componen de 71, 22, 47 y 24 páginas, respectivamente. A su vez, cada una de estas partes se subdivide en otras. La primera, por ejemplo, consta de diez subcapítulos titulados. Y tras su denominación aparece el nombre de la ciudad y la fecha en la que transcurren los hechos. Sabemos, por tanto, que la historia de esta parte inicial arranca en Berlín en 1956, y concluye durante la Navidad de 1971, en la misma ciudad, aunque haya frecuentes saltos atrás. En la segunda parte de la novela desaparece la localización, pero volvemos a encontrárnosla en la tercera, cuando la acción se desarrolla en Barcknang, a partir de 1982 y hasta 1990, en que se produce la reunificación de Alemania. Y después, cuando regresamos a Berlín, durante el verano de 1992.

A tenor de lo dicho, la historia familiar en el Berlín oriental ocupa en la primera parte casi tanto espacio como el resto del relato, provocando un efecto creciente de aceleración de los acontecimientos narrados. Katia cuenta algunos episodios de su existencia, rememora su pasado. Nació en una familia española que tras la guerra había emigrado a la Alemania del Este, donde ella llegó al mundo en 1948. El padre se exilió en 1938, instalándose en Moscú y luego en Dresde (no Dresden, ni tampoco se escribe en español Figueres, sino Figueras; ni Basel, sino Basilea), en 1946, cuando se le unió la madre, tras obtener trabajo y casa. Según ha confesado la autora, el origen de la novela se cifra en el trabajo de la autora en un taller de escritura dirigido por Lara Moreno y en una conversación que mantuvo con el poeta Marcos Ana, quien le habló de los exiliados republicanos españoles en la RDA. Quizá los más conocidos pertenecieran a la familia de Josep Renau, el célebre pintor y autor de extraordinarios fotomontajes, quien se instaló en la RDA en 1958, aunque en la

\footnotetext{
${ }^{4}$ El premio lo concede Radio Nacional al mejor libro del año anterior, en poesía y narrativa, de autores españoles menores de 40 años, con el fin de impulsar una carrera todavía incipiente.
} 
novela no se aluda a ellos. Es indudable que la autora se ha documentado sobre la historia y la vida cotidiana de los lugares y gentes en que transcurre la acción, como es natural, pero sin que ello interfiera en el normal desarrollo de la narración ${ }^{5}$.

Podría decirse que Katia lleva una vida trashumante, quizá producto del desarraigo que padece. En 1990, cuando su matrimonio ha fracasado, lo que sobre todo le reprocha a su marido es que la arranque de su vida, sin proporcionarle a cambio otra existencia consistente (pág. 149). El caso es que llegamos a conocer diversos episodios de su infancia, adolescencia y madurez, cuando ya se ha convertido en madre de familia, casada con Johannes. Entre ellos, su vida en el este, las calles de la capital que recorre, la fuga a través de Checoslovaquia y Austria (casi una historia intercalada) para instalarse en el sur de la Alemania occidental, en el pueblo de Backnang. En suma, abandona a su familia, a sus padres, Manuel e Isabel, y a su hermana Martina, para terminar conviviendo con la de su marido en el oeste, donde emprende una nueva vida, que arranca con una boda en los años setenta y le da dos hijas. Pero podría afirmarse que, en esencia, los protagonistas principales de la narración son tres: Katia, su padre y el país que los acoge, en sus dos versiones: la socialista del este y la capitalista del oeste. Del inevitable contraste entre ambas realidades, ninguna de ellas sale bien parada.

No es esta, sin embargo, la clásica historia de unos intelectuales republicanos exiliados, que son los casos que conocemos mejor, sino la de un militante comunista que tiene que abandonar España tras la guerra, pero que no se dirige a México, ni siquiera a Francia, como era habitual, sino a la Alemania del este, lo que resultaba mucho menos frecuente. Y sin embargo, hoy sabemos bastante de la vida en la RDA, y resulta difícil leer una historia que transcurre en aquel país sin que vuelva a nuestra memoria la extraordinaria película de Florian Henckel, La vida de los otros (2006), que la autora ha debido de tener en cuenta a la hora de escribir esta novela.

Se trata de una familia zarandeada por los avatares de ambas postguerras: la española y la mundial («nuestra guerra» y «la de aquí», distingue el padre), y por la división de un país en dos, de ideologías radicalmente distintas. Pero, siendo importante el contexto histórico, pues condiciona la vida de las gentes, creo que en este caso queda superado por la historia familiar e íntima, por los avatares cotidianos. Si

\footnotetext{
${ }^{5}$ A propósito de la literatura sobre la antigua RDA, traducida al castellano, vid. Aroa Moreno Durán, «Páginas de la Ostalgie», infoLibre, 16 de febrero del 2018 (<https://www.infolibre.es/noticias/ los_diablos_azules/2018/02/16/paginas_ostalgie_75309_1821.html >). Y sobre la historia del exilio republicano español en la antigua RDA, vid. Aurélie Denoyer, L'exil comme patrie. Les réfugiés communistes espagnols en RDA (1950-1989), Presses Universitaires de Rennes, Rennes, 2017; y Matilde Iroa, Españoles tras el Telón de Acero. El exilio republicano y comunista en la Europa socialista, Marcial Pons, Madrid, 2018, págs. 143-156.
} 
el papel que desempeña Katia es importante, así como el del padre, a un nivel distinto, a pesar de que apenas tenga presencia en la segunda y tercera parte de la novela, más allá de recuperarlo en el desenlace; la madre que ha seguido al marido en su exilio no consigue integrarse, pues ni aprende alemán, ni llega a tener una tierra que considere propia, tal y como también le ocurrirá a Katia, aunque resulte ser la más realista de la familia. «Tu padre -le confiesa a Katia- estaba lleno de tontería» (pág. 105). Así, cuando nazca la segunda hija de Katia, llevará su nombre. Madre e hija repiten el mismo recorrido vital, abandonando su mundo y siguiendo a sus parejas, sin que consigan ser felices.

Katia se fuga al oeste por amor, dejando atrás a su familia, de quien ni siquiera se despide, perdiendo todo contacto con ellos, hasta que se produce, primero, la muerte del padre en 1979; y luego el divorcio de Katia, hecho que propicia su vuelta a los orígenes, primero al pueblo de sus padres, Dos Aguas, en la provincia de Valencia, y después a Berlín, donde se encuentra con el desmoronamiento de los suyos, pues la madre va en silla de ruedas y padece Alzheimer, por lo que ni siquiera la reconoce, mientras que la hermana no quiere volver a verla, aunque le lega la maleta con los documentos que le aclararán la historia de su padre, trabajador en una fábrica en Berlín. Cuando concluye la narración sabemos que la fuga no fue una decisión acertada, ni tampoco su precipitado matrimonio, en el conjunto de unas vidas que nunca llegan a enderezarse del todo, a disfrutar de una existencia normal.

La autora maneja bien la trama, valiéndose de algunos de los ingredientes propios de las historias de espías, aunque no sea el enigma lo que realmente cuente, pero el relato se enriquece con sus procedimientos y habitual retórica, con el manejo de una cierta intriga (¿tiene el padre una aventura?, pág. 73), tanto durante la fuga hacia el oeste, como cuando Katia -en el desenlace- descubre las actividades políticas de su progenitor, su papel de informante del gobierno socialista entre los emigrantes españoles.

El simbolismo de ciertos objetos y situaciones también desempeña un papel en la configuración de la historia, empezando por el principal que es el muro. Aquí actúa como metáfora que va más allá de la división física, puesto que Katia parece llevárselo con ella al oeste, mientras que la familia de su marido también se atrinchera frente a ella (su suegro había luchado en la guerra con los nazis), pues no llegan a tratarla como a una igual, por su doble condición de ciudadana del este e hija de republicanos españoles exiliados, con una identidad por tanto difusa. Otros objetos y situaciones también desempeñan un determinado papel en la trama, como las fotografías (págs. 11, 12, 25, 27, 64, 119, 144, 175); la insignia roja del PCE, con la hoz y el martillo, que Katia se llevará consigo; las dificultades para adquirir alimentos básicos o que les llegue el correo en el Este; las medias de cristal; la novela de Anna 
Seghers, La séptima cruz (1917) y el Canto general (1950) de Neruda, el poeta comunista a quien le conceden el Nobel en 1971; las diferentes formas de diversión; las singularidades de los comunistas cubanos; la cristalería que va rompiéndose conforme se resquebraja su matrimonio; y la maleta que guarda los papeles del padre.

Tampoco faltan en el relato de Katia los principales ritos de paso: el primer amor; sus mejores amigas: la cubana Julia y la alemana Frieda; el extraño e insistente cortejo de Johannes, futuro ingeniero, marido y padre de sus hijas; el inicio de los estudios universitarios de Germanística en la Humboldt; y en especial esa vida nueva que emprende. Se trata, así, de una novela realista escrita con un estilo claro y cuidado, pero metafórico, cuyo lenguaje se vale a veces de los procedimientos de lo poético, aunque por desgracia no escaseen ni las erratas, ni ciertos errores, que una corrección de estilo hubiera evitado.

En el título de la novela prevalece la condición de hija y de comunista, sobre la de mujer, amante, esposa o madre, y por tanto -digamos- el pasado sobre el presente. Pero si ella es la hija del comunista, su marido es el hijo del nazi, aunque nunca se formule así en la novela, y sea evidente que mientras se hunde el régimen comunista del este, los antiguos nazis siguen en libertad en el Oeste. En cuanto a las denominaciones de los capítulos, organizados dos a dos, se alude a la geografía, el Este y el otro lado, y a la tierra, bien sea de nadie o la del padre. Esto es, la patria (Vaterland). En suma, lo mejor de la novela de Aroa Moreno Durán es que en ella intuimos la promesa de una buena narradora.

Pero concluyamos. El nuevo siglo se ha caracterizado de momento por el estallido de la violencia terrorista, por numerosos conflictos políticos, así como por la crisis económica en el 2008 y el desarrollo del populismo, sea este de derechas, de extrema derecha, o de izquierdas, amenazando el estado de bienestar que se fue asentando en Europa tras el desenlace de la Segunda Guerra Mundial. En España, como miembro de la Unión Europea, hemos padecido esos graves avatares de la historia, pero a ellos tendríamos que sumar nuestros propios conflictos internos: el paro, la corrupción, la dificultad de los jóvenes a la hora de acceder a puestos de trabajo dignos y el separatismo catalán, mentiroso, insolidario y racista, entre los más graves. Estos avatares de la Historia serán pronto materia novelable, como ya lo ha sido la corrupción urbanística, el terrorismo vasco, la precariedad laboral de los jóvenes o la intrínseca condicion femenina, acosadas las mujeres por la violencia y el desigual trato laboral. Pues la novela quizá sea la forma literaria más adecuada para la reflexión, capaz de dar curso a nuestras dudas, al pensamiento paradójico, pero también la indicada para llamar la atención sobre algunas convicciones por las que deberíamos seguir luchando: la defensa de la democracia, del estado de derecho, la igualdad y la solidaridad con los menos favorecidos, sean estos compatriotas o 
vengan de allende nuestras fronteras. Por tanto, se ocupe del presente más rabioso o del pasado remoto, la novela no tendría que ser solo una fuente de entretenimiento, ni un mero producto comercial, sino un espacio para el pensamiento y la reflexión, mientras que la lectura debería suponer un tiempo para el recogimiento y el disfrute, pero también -escritura y lectura- para la concienciación de los problemas públicos y privados que enturbian la convivencia pacífica, alejándonos del bienestar, de la felicidad. La crítica literaria de actualidad, y la académica que se ocupa de la narrativa del presente, está obligada a apostar por el análisis y la defensa de estas novelas más complejas y ambiciosas, comprometidas con la historia del género, con las acuciantes realidades del presente. Si como afirmaba recientemente el escritor francés Pierre Lemaitre la misión de la literatura consiste en hacer el mundo algo más comprensible, los novelistas disponen hoy de amplias posibilidades para poder cumplir con su tarea, sin tener por qué embriagarse con la espuma de los días ${ }^{6}$.

\footnotetext{
${ }^{6} C f$. Laura Fernández, Pierre Lemaitre. Escritor. La crítica literaria francesa es una manada de lobos", El País, 11 de marzo del 2019. Los comentarios que le dedico a las novelas de Mario Cuenca Sandoval y Andrés Neuman fueron publicados en el suplemento literario Los diablos azules del diario infoLibre, aunque aquí aparezcan levemente corregidos y ampliados, mientras que la introducción, la conclusión y las páginas dedicadas a las novelas de Esther García Llovet y Aroa Moreno Durán fueron escritas para esta ocasión. El conjunto, por tanto, es inédito. Por último, quiero darles las gracias por la ayuda que me han prestado a Fernando García Lara y Manuel Aznar Soler.
} 